\title{
Kajian Pusat-Pusat Pelayanan Di Kabupaten Kampar
}

\author{
Rona Muliana $^{1}$, Puji Astuti², Akmal Fadli ${ }^{3}$ \\ ${ }^{1,2,3}$ Program Studi Teknik Perencanaan Wilayah dan Kota Universitas Islam Riau \\ Jalan Kaharuddin Nasution 113 Pekanbaru 28284
}

\begin{abstract}
Abstrak
Pusat-pusat pelayanan merupakan suatu aglomerasi dari berbagai kegiatan atau aktivitas serta aglomerasi dari berbagai prasarana dan sarana yang dapat menunjang pertumbuhan dan perkembangan wilayah. Pembangunan pusat-pusat pelayanan selain untuk memenuhi kebutuhan masyarakat juga diharapkan mampu mendukung pengembangan wilayah. Adapun tujuan penelitian ini adalah: (1) mengidentifikasi struktur pusat-pusat pelayanan di Kabupaten Kampar berdasarkan RTRW Kabupaten Kampar; (2) mengidentifikasi struktur pusatpusat pelayanan di Kabupaten Kampar berdasarkan analisis skalogram dan indeks sentralitas; (3) menyusun rekomendasi struktur pusat-pusat pelayanan di Kabupaten Kampar.

Metode penelitian adalah deduktif kuantitatif dengan menggunakan analisis skalogram dan indeks sentralitas. Hasil penelitian menunjukkan Dari draft RTRW Kabupaten Kampar dengan hasil analisis skalogram dan indeks sentralitas terdapat perbedaan struktur pusat-pusat pelayanan.

Dari analisis skalogram dan indeks sentralitas tidak terdapat hirarki II dan hirarki III sehingga terjadi pemusatan fasilitas pada hirarki 1 yakni Kota Bangkinang sebagai ibukota Kabupaten. Setelah dibandingkan struktur pusatpusat pelayanan di Kabupaten Kampar berdasarkan draft RTRW dengan analisis skalogram dan indeks sentralitas, maka direkomendasikan struktur pusat-pusat pelayanan di Kabupaten Kampar terdiri dari 5 hirarki yaitu hirarki I berada di Kecamatan Bangkinang Kota, hirarki II berada di Kecamatan Tapung, Kampar Kiri, Siak Hulu, dan Tapung Hulu, hirarki III berada di Kecamatan Tapung Hilir, Kampar Kiri Hilir, dan XIII Koto Kampar, hirarki IV berada di Kecamatan Bangkinang, Gunung Sahilan, Perhentian Raja, Salo, dan Kampar, hirarki V berada di Kecamatan Kampar Kiri Tengah, Rumbio Jaya, Kuok, Kampar Timur, Koto Kampar Hulu, Tambang, Kampar Utara, dan Kampar Kiri Hulu.
\end{abstract}

Kata-kata kunci : Pusat-Pusat Pelayanan, Analisis Skalogram, Indeks Sentralitas 


\section{PENDAHULUAN}

Pusat pelayanan atau lebih dikenal dengan central place menurut Christaller (1933) dalam Pane (2013) merupakan kotakota yang menyajikan barang dan jasa bagi masyarakat di wilayah sekelilingnya dengan membentuk suatu hirarki berdasarkan jarak dan ambang batas penduduk. Pembagian hirarki pelayanan tersebut, mengakibatkan suatu kota (dengan hirarki pelayanan paling tinggi) secara alami memiliki potensi daya tarik yang besar dan berpengaruh besar bagi daerah-daerah yang kekuatannya lebih kecil, dimana kota tersebut mempunyai kemampuan menarik potensi, sumber daya dari daerah lain dan kota di bawahnya. Jadi pusat-pusat pelayanan merupakan suatu aglomerasi dari berbagai kegiatan atau aktivitas serta aglomerasi dari berbagai prasarana dan sarana yang dapat menunjang pertumbuhan dan perkembangan wilayah.

Pengembangan wilayah dilakukan bertujuan untuk mempercepat perkembangan sosial ekonomi masyarakat, mengurangi kesenjangan antar wilayah, dan menjaga kelestarian lingkungan hidup pada suatu wilayah.Kesenjangan wilayah atau yang disebut dengan ketimpangan wilayah merupakan fenomena perbedaan antar wilayah dikarenakan ketidakmerataan pembangunan antar wilayah. Salah satu cara yang dapat dilakukan untuk mengatasi kesenjangan adalah dengan mengoptimalkan pusat-pusat pelayanan.

Kabupaten Kampar merupakan salah satu kabupaten di Provinsi Riau yang memiliki wilayah administrasi yaitu $11.289,28 \mathrm{~km}^{2}$, dengan jumlah kecamatan sebanyak 21 kecamatan yang memiliki kondisi alam dan kondisi sosial yang bervariasi. Ibu Kota Kabupaten Kampar terletak di Kecamatan Bangkinang yang sekaligus berperan sebagai pusat pelayanan dengan ketersediaan berbagai fasilitas pelayanan sosial ekonomi.

Kabupaten Kampar tidak terlepas dari masalah pengembangan wilayah terutama yang berkaitan dengan pusat pelayanan. Permasalahan umum yang terjadi terkait pusat pelayanan adalah persebaran fasilitas tidak merata dan tingginya konsentrasi fasilitas pelayanan di wilayah tertentu yang pada umumnya adalah wilayah pusat. Kecenderungan pembangunan wilayah yang dikonsentrasikan hanya pada pusat dan mengabaikan peranan dari hinterland akan memperjelas kesenjangan antar wilayah. Kesenjangan pembangunan di Kabupaten Kampar terjadi antara kawasan utara, tengah dan selatan (draft RTRW Kabupaten Kampar, 2010). Berdasarkan permasalahan ini perlu untuk mengkaji kembali struktur pusat-pusat pelayanan di Kabupaten Kampar.

Adapun tujuan dalam penelitian ini adalah: (1) mengidentifikasi struktur pusatpusat pelayanan di Kabupaten Kampar berdasarkan RTRW Kabupaten Kampar; (2) mengidentifikasi struktur pusat-pusat pelayanan di Kabupaten Kampar berdasarkan analisis skalogram dan indeks sentralitas; (3) menyusun rekomendasi struktur pusat-pusat pelayanan di Kabupaten Kampar.

\section{TINJAUAN PUSTAKA}

Pusat pelayanan merupakan titiktitik pertumbuhan yang terjadi di beberapa tempat tertentu saja karena adanya kekuatan penggerak pembangunan, dimana kekuatan tersebut dapat merangsang kegiatankegiatan lainnya untuk tumbuh dan berkembang. Kegiatan-kegiatan tersebut mempunyai kecendrungan untuk mengelompok membentuk suatu kesatuan yang pada akhirnya menjadi pusat dari kegiatan atau disebut sebagai pusat pelayanan. Jadi pusat-pusat pelayanan merupakan suatu aglomerasi dari berbagai kegiatan atau aktivitas serta aglomerasi dari berbagai prasarana dan sarana yang dapat menunjang pertumbuhan dan perkembangan wilayah (Pane, 2013).

Pusat Pelayanan atau pusat wilayah dimaksudkan sebagai bagian dari kehidupan yang mempunyai fungsi pelayanan, yang berarti jasa dari pusa tpelayanan sangat dibutuhkan oleh masyarakat. Pusat pelayanan merupakan tempat yang berguna sebagai basis aktivitas penduduk dalam memperoleh barang dan jasa untuk 
memenuhi kebutuhannya, fasilitas- fasilitas pelayanan yang dibutuhkan terkonsentrasi di tempat tersebut (Parera, 2004 dalam Nirwani, 2014).

Perkembangan tiap jenis pusat pelayanan sangat bergantung pada jumlah penduduk yang melayani dan dilayani. Peningkatan jumlah penduduk biasanya disertai dengan peningkatan kemampuan untuk melayani sehingga menimbulkan adanya tingkatan-tingkatan diantara permukiman dari wilayah yang bersangkutan (hierarchy of towns) (Koestoer, 1995 dalam Nirwani, 2014).

Dalam Budiharsono (2001:137) dijelaskan konsep pusat pelayanan ditelaah dan diadaptasi dari beberapa teori yang dikemukakan oleh:

a. Perroux tentang pusat pertumbuhan dan kutub pertumbuhan dalam ruang ekonomi.

Dalam teori ini dinyatakan bahwa pembangunan kota atau wilayah di mana pun bukan merupakan suatu proses yang terjadi secara serentak, tetapi mucul di tempat-tempat tertentu dengan kecepatan dan intensitas yang berbeda-beda. Tempat-tempat atau kawasan yang menjadi pusat pembangunan tersebut dinamakan pusat-pusat atau kutub-kutub pertumbuhan. Dari kutub-kutub tersebut selanjutnya proses pembangunan akan menyebar ke wilayah-wilayah lain di sekitarnya atau ke pusat-pusat yang lebih rendah.Dengan kata lain, kutub pertumbuhan dapat memberikan imbas (trickling down effect) bagi wilayah atau daerah di sekitarnya.

b. Boudeville tentang kutub pertumbuhan dan pusat pertumbuhan dalam dimensi geografis.

Menurut Boudeville, pusat pertumbuhan adalah sekumpulan fenomena geografis dari semua kegiatan yang ada di permukaan Bumi. Suatu kota atau wilayah kota yang mempunyai industri populasi yang kompleks, dapat dikatakan sebagai pusat pertumbuhan. Industri populasi merupakan industri yang mempunyai pengaruh yang besar (baik langsung maupun tidak langsung) terhadap kegiatan lainnya.

c. Walter Christaller dan August Losch tentang ukuran, lokasi, distribusi dan pengelompokan kegiatan ekonomi.

Teori tempat sentral dikemukakan oleh Walter Christaller pada tahun 1933, seorang ahli geografi dari Jerman.Teori ini didasarkan pada lokasi dan pola persebaran permukiman dalam ruang. Dalam suatu ruang kadang ditemukan persebaran pola permukiman desa dan kota yang berbeda ukuran luasnya. Teori pusat pertumbuhan dari Christaller ini diperkuat oleh pendapat August Losch pada tahun 1945, seorang ahli ekonomi Jerman.

Keduanya berkesimpulan, bahwa carayang baik untuk menyediakan pelayanan berdasarkan aspek keruangan dengan menempatkan aktivitas yang dimaksud pada hierarki permukiman yang luasnya meningkat dan lokasinya ada pada simpul-simpul jaringan heksagonal. Lokasi ini terdapat pada tempat sentral yang memungkinkan partisipasi manusia dengan jumlah maksimum, baik mereka yang terlibat dalam aktivitas pelayanan maupun yang menjadi konsumen dari barang-barang yang dihasilkannya.

d. Gunnar Myrdal tentang spreadbackwash effects pertumbuhan ekonomi dalam tata ruang.

Menurut Gunnar Myrdal dalam teorinya, jika dilakukan pembangunan ekonomi dalam suatu negara, akan muncul 2 faktor, yaitu pertama : memperburuk keadaan ekonomi bagi daerah miskin yang disebut dengan backwash effects dan kedua : mendorong daerah miskin menjadi lebih maju disebut dengan spread effects/trickle-down effects. Pembangunan ekonomi menghasilkan suatu proses sebab-menyebab sirkuler yang membuat si kaya mendapat keuntungan semakin banyak, dan 
mereka yang tertinggal di belakang menjadi semakin terhambat. Dampak balik (backwash effects) cenderung membesar dan dampak sebar (spread effects) cenderung mengecil. Secara kumulatif kecenderungan ini semakin memperburuk ketimpangan internasional dan menyebabkan ketimpangan regional diantara negaranegara terbelakang.

e. Hirschman tentang trickling down dan polarization effects suatu pertumbuhan ekonomi.

Trickle down effects adalah perkembangan meluasnya pembagian pendapatan. Teori "trickle down effects" dari pola pembangunan yang diterapkan di wilayah miskin di negara berkembang dirasa tidak berhasil memecahkan masalah pengangguran, kemiskinan dan pembagian pendapatan yang tidak merata, baik di dalam negara berkembang masing maupun antara negara maju dengan negara berkembang.

f. Hagerstestrand dan Pottier tentang difusi inovasi dalam tata ruang dan sumbu-sumbu pertumbuhan.

g. Galpindan Kolb tentang anatomi sosial dari masyarakat pertanian (Roi dan Patil, 1976 dalam Budiharsono, 2001).

Konsep pusat pelayanan mempunyai beberapa asumsi yaitu:

1) Penduduk didistribusikan pada beragam ukuran permukiman.

2) Penduduk mempunyai kebutuhan biofisik sama baiknya dengan kebutuhan sosial ekonomi.

3) Penduduk menggunakan sumber daya alam dan manusia seperti barang- barang dan jasa untuk kebutuhan mereka.

4) Penduduk membentuk permukiman dalam bentuk rumah, dusun kecil, desa dan kota serta meneruskan untuk tinggal bersama selama sumber daya mencukupi kebutuhan mereka.

5) Penduduk menggunakan sumber daya untuk kebutuhan dasar yang dibatasi atau keinginan yang terbatas.

6) Penduduk berpindah ke tempat lain (migrasi) untuk mencari barangbarang dan jasa yang tidak mereka dapatkan di permukiman mereka.

Suatu ciri umum dari daerah-daerah nodal adalah bahwa penduduk kota tidaklah tersebar secara merata diantara pusat-pusat yang sama besarnya tetapi tersebar diantara pusat-pusat yang besarnya berbeda-beda yang secara keseluruhan membentuk suatu hirarki perkotaan (Harry W, 1991 dalam Pane, 2013).

Pusat dan daerah belakang (hinterland) dalam suatu wilayah nodal mempunyai hubungan yang bersifat simbiotik dan mempunyai fungsi yang spesifik sehingga keduanya tergantung secara internal. Fungsi dari pusat antaralain adalah sebagai berikut:

1) Sebagai pusat permukiman,

2) Pusat pelayanan,

3) Pusat industri, dan

4) Pusat perdagangan bahan mentah.

Fungsi daerah belakang adalah sebagai berikut:

1) Sebagai penyedia bahan mentah dan sumber daya dasar,

2) Daerah pemasaran barang-barang industri,

3) Pusat kegiatan pertanian.

Perkembangan suatu pusat sangat tergantung pada perkembangan daerah belakang atau sebaliknya(Budiharsono, 2001: 137).

Faktor- faktor yang menyebabkan timbulnya pusat-pusat wilayah sebagai berikut:

a. Faktor lokasi ekonomi

Menjelaskan letak suatu wilayah yang strategis menyebabkan suatu wilayah dapat menjadi suatu pusat.

b. Faktor ketersediaan sumber daya Menjelaskan bahwa ketersediaan sumber daya alam pada suatu wilayah akan menyebabkan wilayah tersebut menjadi pusat.

c. Kekuatan aglomerasi

Kekuatan aglomerasi terjadi karena ada sesuatu yang mendorong kegiatan ekonomi sejenis untuk 
mengelompok pada suatu lokasi karena adanya sesuatu keuntungan. Selanjutnya akan menyebabkan timbulnya pusat-pusat wilayah.

d. Faktor investasi pemerintah

Ketiga faktor diatas menyebabkan timbulnya pusat-pusat wilayah secara alamiah.Sedangkan faktor investasi pemerintah merupakan sesuatu yang sengaja dibuat(artificial).(Budiharsono,

2001: 138)

Pada dasarnya pusat wilayah mempunyai hierarki. Hierarki dari suatu pusat ditentukan oleh beberapa faktor, yaitu:

1) Jumlah penduduk yang bermukim pada wilayah pusat tersebut.

2) Jumlah fasilitas pelayanan umum yang tersedia.

3) Jumlah dan jenis fasilitas pelayanan umum yang tersedia. (Budiharsono, 2001: 138)

Budiharsono,

(2001:

menyebutkan bahwasemakin besar jumlah penduduk dan semakin banyak jumlah fasilitas serta jumlah jenis fasilitas pada suatu pusat maka semakin tinggi pula hierarki dari pusat tersebut.Dalam mendapatkan pelayanan sederhana seperti barang- barang kebutuhan dasar, seseorang dapat memperolehnya dari pusat-pusat yang berhierarki rendah.Sedangkan pelayananpelayanan yang lebih tinggi dapat diperoleh pada wilayah yang berhierarki tinggi. Pertumbuhan penduduk yang semakin cepat akan cenderung mengakibatkan pertambahan jumlah fasilitas dan jumlah jenis fasilitas yang semakin banyak begitu juga sebaliknya.

Tujuan diidentifikasinya pusat pelayanan adalah sebagai berikut:

1) Dapat mengetahui pusat-pusat pelayanan dan daerah pelayanan pada tingkat yang berbeda.

2) Penentuan dari fasilitas infrastruktur pokok untuk memuaskan kebutuhan beragam sektor dari penduduk, dan

3) Pengintegrasian atau pengelompokan pelayanan pada tingkat wilayah dan hubungannya dengan jaringan jalan (Budiharsono, 2001: 138).

Wilayah pelayanan suatu pusat dan wilayah pelayanan suatu jenis fasilitas pelayanan dipengaruhi:

a. Keadaaan sarana dan prasarana transportasi.

b. Jumlah dan kapasitas sarana pelayanan umum perjumlah penduduk.

c. Jumlah dan kapasitas sarana pelayanan umum perluas areal.

Pusat pelayanan merupakan tempat yang berfungsi melayani kebutuhan akan fasilitas-fasilitas sosial ekonomi. Menurut Muta'ali, (2000: 14-16) membagi fasilitas sosial ekonomi menjadi: (a) Pelayanan sosial dasar, meliputi: pendidikan, dan kesehatan. (b) Pelayanan ekonomi, meliputi: pasar, toko, reparasi, bank/lembaga keuangan, dan koperasi. (c) Pelayanan pendukung sosial ekonomi, meliputi: kualitas jalan, dan kuantitas jalan. (d) Administrasi kelembagaan, meliputi: LKMD, Pegawai kantorpemerintahan dan instansi pemerintahan.

\section{METODE PENELITIAN}

Paradigma penelitian yang diacu dalam penelitian ini adalah paradigma rasionalistik. Paradigma rasionalistik meyakini bahwa sumber pengetahuan yang dapat dipercaya adalah akal, dimana empiris hanya berfungsi meneguhkan pengetahuan yang diperoleh dari akal.

Metode penelitian yang diacu dalam penelitian ini adalah metode penelitian deduktif kuantitatif. Wilayah studi dalam penelitian ini adalah Kabupaten Kampar.

Analisis data dilakukan dengan analisis deskriptif kuantitatif. Metode kuantitatif yang digunakan adalah analisis skalogram dan indeks sentralitas.

\section{HASIL PENELITIAN DAN PEMBAHASAN}

\section{Struktur Pusat-Pusat Pelayanan di Kabupaten Kampar Berdasarkan RTRW Kabupaten Kampar}

Struktur ruang wilayah kabupaten merupakan kerangka tata ruang wilayah 
kabupaten yang tersusun atas konstelasi pusat-pusat kegiatan yang berhierarki satu sama lain dihubungkan oleh sistem jaringan prasarana wilayah kabupaten terutama jaringan transportasi. Struktur pusat-pusat pelayanan di Kabupaten Kampar berdasarkan RTRW Kabupaten Kampar adalah sebagai berikut:

\section{Tabel 1}

Struktur Pusat-Pusat Pelayanan di Kabupaten Kampar Berdasarkan RTRW Kabupaten Kampar

\begin{tabular}{|c|c|c|c|}
\hline No & $\begin{array}{c}\text { Ibukota } \\
\text { Kecamatan/Kabupaten }\end{array}$ & $\begin{array}{l}\text { Hirarki } \\
\text { Fungsi }\end{array}$ & Fungsi Utama \\
\hline 1 & Bangkinang & PKW & $\begin{array}{ll}- & \text { Pemerintah } \\
& \text { Kabupaten } \\
\text { - } & \text { Perdagangan \& } \\
& \text { Jasa } \\
\text { - } & \text { Pendidikan } \\
\text { - } & \text { Kesehatan } \\
\text { - } & \text { Kebudayaan } \\
\text { - } & \text { Pariwisata } \\
\end{array}$ \\
\hline 2 & Petapahan & PKLp & $\begin{array}{ll}\text { - } & \text { Pemerintahan } \\
\text { - } & \text { Kecamatan } \\
& \text { Perdagangan \& } \\
\text { - } & \text { Jasa } \\
\text { - } & \text { Pendidikan } \\
\text { - } & \text { Industri agro } \\
\end{array}$ \\
\hline 3 & Lipat Kain & PKLp & $\begin{array}{ll} & \text { Pemerintahan } \\
& \text { Kecamatan } \\
\text { - } & \text { Perdagangan \& } \\
& \text { Jasa } \\
\text { - } & \text { Pendidikan } \\
\text { - } & \text { Kesehatan } \\
\text { - } & \text { Wisata } \\
\text { Kebudayaan }\end{array}$ \\
\hline 4 & Kota Garo & PPK & $\begin{array}{ll}\text { - } & \text { Pemerintahan } \\
& \text { Kecamatan } \\
\text { - } & \text { Perdagangan \& } \\
& \text { Jasa } \\
\text { - } & \text { Pendidikan } \\
\text { - } & \text { Kesehatan } \\
\text { - } & \text { Fasilitas Transit }\end{array}$ \\
\hline 5 & Sungai Pagar & PPK & $\begin{array}{ll}\text { - } & \text { Pemerintahan } \\
& \text { Kecamatan } \\
\text { - } & \text { Perdagangan \& } \\
& \text { Jasa } \\
\text { - } & \text { Pendidikan } \\
\text { - } & \text { Kesehatan } \\
\end{array}$ \\
\hline 6 & Batu Bersurat & PPK & $\begin{array}{ll}\text { - } & \text { Pemerintahan } \\
\text { - } & \text { Kecamatan } \\
& \text { Perdagangan \& } \\
\text { - } & \text { Pendidikan } \\
\text { - } & \text { Kesehatan } \\
\text { - } & \text { Kebudayaan } \\
\text { - } & \text { Pariwisata } \\
\end{array}$ \\
\hline 7 & Gema & PPL & $\begin{array}{l}\text { - Pemerintahan } \\
\text { Kecamatan }\end{array}$ \\
\hline
\end{tabular}

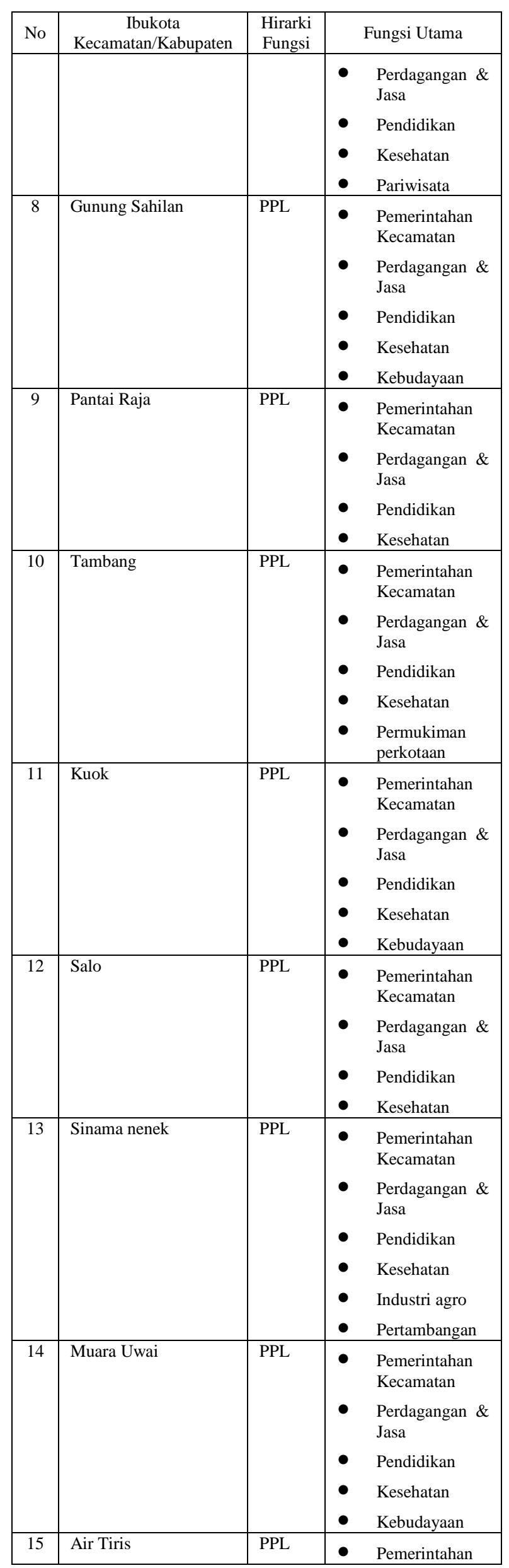




\begin{tabular}{|c|c|c|c|}
\hline No & $\begin{array}{c}\text { Ibukota } \\
\text { Kecamatan/Kabupaten }\end{array}$ & $\begin{array}{l}\text { Hirarki } \\
\text { Fungsi }\end{array}$ & Fungsi Utama \\
\hline & & & $\begin{array}{ll} & \text { Kecamatan } \\
\text { - } & \text { Perdagangan \& } \\
& \text { Jasa } \\
\text { - } & \text { Pendidikan } \\
\text { - } & \text { Kesehatan } \\
\text { - } & \text { Kebudayaan }\end{array}$ \\
\hline 16 & Kampar & PPL & $\begin{array}{ll}\text { - } & \text { Pemerintahan } \\
& \text { Kecamatan } \\
\text { - } & \text { Perdagangan \& } \\
& \text { Jasa } \\
\text { - } & \text { Pendidikan } \\
\text { - } & \text { Kesehatan } \\
\end{array}$ \\
\hline 17 & Taratak & PPL & $\begin{array}{ll}\text { - } & \text { Pemerintahan } \\
& \text { Kecamatan } \\
\text { - } & \text { Perdagangan \& } \\
& \text { Jasa } \\
\text { - } & \text { Pendidikan } \\
\text { - } & \text { Kesehatan } \\
\end{array}$ \\
\hline 18 & Sawah & PPL & $\begin{array}{ll}\text { - } & \text { Pemerintahan } \\
& \text { Kecamatan } \\
\text { - } & \text { Perdagangan \& } \\
& \text { Jasa } \\
\text { - } & \text { Pendidikan } \\
\text { - } & \text { Kesehatan }\end{array}$ \\
\hline
\end{tabular}

Sumber : Draft RTRW Kabupaten Kampar, 2010

\section{Struktur Pusat-Pusat Pelayanan di Kabupaten Kampar Berdasarkan Analisis Skalogram dan Indeks Sentralitas}

Analisis skalogram digunakan untuk melakukan analisis kelengkapan fungsi fasilitas pada suatu wilayah dengan metode menuliskan ada atau tidaknya (fasilitas sosial ekonomi), yaitu dengan mengisikan angka 1 bila fasilitas tersebut terdapat pada suatu wilayah dan mengisikan angka 0 bila fasilitas tersebut tidak terdapat di suatu wilayah. Selanjutnya analisis skalogram dapat dikembangkan untuk menentukan indek sentralias terbobot.

Analisis indeks sentralitas digunakan untuk melihat tingkat keterpusatan fasilitas pelayanan, pada suatu wilayah, analisis ini tidah hanya berdasarkan jumlah fungsi atau fasilitas, tetapi juga berdasarkan frekuensi keberadaan fungsi atau fasilitas pelayanan, semakin tinggi nilai sentralitasnya maka semakin tinggi pula hirarki wilayah tersebut.
Adapun jenis fasilitas yang digunakan dalam analisis skalogram dan indeks sentralitas adalah sebagai berikut:

Tabel 2 Jenis Fasilitas untuk Analisis Skalogram dan Indeks Sentralitas di Kabupaten Kampar

\begin{tabular}{|c|c|c|}
\hline No & $\begin{array}{c}\text { Fungsi } \\
\text { Fasilitas }\end{array}$ & Nama Fasilitas \\
\hline 1 & $\begin{array}{l}\text { Fasilitas } \\
\text { Pendidikan }\end{array}$ & $\begin{array}{l}\text { - } \text { Taman Kanak- } \\
\text { Kanak/TK } \\
\text { - Sekolah Dasar/SD } \\
\text { - Sekolah Lanjutan } \\
\text { Tingkat } \\
\text { Pertama/SLTP } \\
\text { - Sekolah Lanjutan } \\
\text { Tingkat } \\
\text { Atas/SLTA } \\
\text { - Pergutuan } \\
\text { Tinggi/PT }\end{array}$ \\
\hline 2 & $\begin{array}{l}\text { Fasilitas } \\
\text { Kesehatan }\end{array}$ & $\begin{array}{l}\text { - Posyandu } \\
\text { - Poliklinik } \\
\text { - Puskesmas } \\
\text { - Puskesmas } \\
\text { - Pembantu } \\
\text { - Dokter Praktek } \\
\text { - Rumah Sakit }\end{array}$ \\
\hline 3 & $\begin{array}{l}\text { Fasilitas } \\
\text { Peribadatan }\end{array}$ & $\begin{array}{l}\text { - Musholla } \\
\text { - Masjid } \\
\text { - Gereja }\end{array}$ \\
\hline 4 & $\begin{array}{l}\text { Fasilitas } \\
\text { Ekonomi }\end{array}$ & $\begin{array}{l}\text { - Pasar } \\
\text { - Toko } \\
\text { - Warung/Kios } \\
\text { - KUD } \\
\text { - Bank }\end{array}$ \\
\hline
\end{tabular}

Sumber : Hasil Analisis, 2017

Berdasarkan analisis skalogram dan indeks sentralitas fasilitas pendidikan, kesehatan, peribadatan dan ekonomi diatas menunjukkan kecamatan yang berorde atau hirarki I adalah Kecamatan Bangkinang Kota, hirarki II dan III tidak ada kecamatan, hirarki IV terdiri 9 (sembilan) kecamatan, sedangkan hirarki $\mathrm{V}$ terdiri dari 11 (sebelas) kecamatan. Untuk lebih jelas dapat dilihat pada Tabel 3 Hasil Hirarki Pusat Pelayanan di Kabupaten Kampar Menggunakan Analisis Skalogram dan Indeks Sentralitas berikut ini. 
Tabel 3 Hasil Hirarki Pusat Pelayanan di Kabupaten Kampar Menggunakan Analisis

Skalogram dan Indeks Sentralitas

\begin{tabular}{|c|l|r|r|c|}
\hline No & \multicolumn{1}{|c|}{ Kecamatan } & $\begin{array}{c}\text { Jumlah } \\
\text { Jenis/Fungsi } \\
\text { Fasilitas }\end{array}$ & $\begin{array}{c}\text { Indeks } \\
\text { Sentralitas }\end{array}$ & Hirarki \\
\hline 1 & Bangkinang Kota & 18 & 201 & I \\
\hline 2 & Siak Hulu & 18 & 110 & IV \\
\hline 3 & Tapung Hulu & 18 & 110 & IV \\
\hline 4 & Salo & 16 & 99 & IV \\
\hline 5 & Kampar & 16 & 95 & IV \\
\hline 6 & Tapung & 17 & 90 & IV \\
\hline 7 & Tapung Hilir & 17 & 90 & IV \\
\hline 8 & Bangkinang & 17 & 90 & IV \\
\hline 9 & Gunung Sahilan & 17 & 90 & IV \\
\hline 10 & Perhentan Raja & 17 & 90 & IV \\
\hline 11 & Kampar Kiri Tengah & 16 & 84 & V \\
\hline 12 & Rumbio Jaya & 16 & 84 & V \\
\hline 13 & XIII Koto Kampar & 16 & 81 & V \\
\hline 14 & Kuok & 16 & 81 & V \\
\hline 15 & Kampar Timur & 16 & 81 & V \\
\hline 16 & Koto Kampar Hulu & 15 & 78 & V \\
\hline 17 & Kampar Kiri & 15 & 75 & V \\
\hline 18 & Kampar Kiri Hilir & 15 & 75 & V \\
\hline 19 & Tambang & 15 & 75 & V \\
\hline 20 & Kampar Utara & 13 & 62 & V \\
\hline 21 & Kampar Kiri Hulu & 12 & 57 & V \\
\hline
\end{tabular}

Sumber : Hasil Analisis, 2017

Berdasarkan tabel diatas teridentifikasi bahwa, hanya terdapat 1 (satu) kecamatan yang dapat dikategorikan sebagai pusat pelayananatau secara hirarki berada pada hirarki/orde I dengan kategori nilai indeks sentralitas sangat tinggi menunjukkan ketersediaan dan keterpusatan fasilitas sosial ekonominya lebih tinggi dari kecamatan lain. Kecamatan tersebut ialah Kecamatan Bangkinang Kota, hal ini memperjelas bahwa konsentrasi fasilitas pelayanan berada pada Ibu Kota Kabupaten Kampar. Pada orde/hirarki ke II dan III tidak terdapat kecamatan, dapat diartikan bahwa terjadi kesenjangan antara Kecamatan Bangkinang Kota dengan kecamatan lain. Untuk itu perlunya memperkecil kesenjangan dengan melihat kecamatan yang dapat diprioritaskan pengembangannya melalui percepatan pembangunan terutama fasilitas sosial ekonomi.

\section{Rekomendasi Struktur Pusat-Pusat Pelayanan di Kabupaten Kampar}

Jika dilihat berdasarkan struktur ruang Kabupaten Kampar yang tertuang dalam draft Rencana Tata Ruang Wilayah (RTRW) Kabupaten Kampar Tahun 20102030 terdapat perbedaan dengan hasil analisis menggunakan skalogram dan indeks sentralitas.

Berikut perbandingan struktur pusat-pusat pelayanan berdasarkan RTRW dengan hasil analisis skalogram dan indeks sentralitas:

Berdasarkan tabel perbandingan antara RTRW Kabupaten Kampar Tahun 20102030 dengan hasil analisis skalogram dan indeks sentralitas menunjukkan adanya perbedaan, untuk itu dilakukan penyesuaian antara hasil analisis dengan kebijakan RTRW dalam merekomendasikan pusatpusat pelayanan di Kabupaten Kampar. Kecamatan Bangkinang Kota berada pada 
Hirarki I sebagai pusat pelayanan skala regional. Namun, setiap pusat pelayanan mempunyai keterbatasan kemampuan untukmelayani sejumlah penduduk tertentu dengan wilayah pelayanan yang tertentu pula, oleh karena itu selain pusat pelayanan diperlukan pula sub pusat yang merupakan satu kesatuan sistem, dengan demikian maka terwujud pembagian tugas berikut wilayah pelayanannya.

Berdasarkan hasil analisis skalogram dan indeks sentralitas diketahui hirarki II dan III tidak terdapat kecamatan, hal ini dapat berarti bahwa terjadi ketimpangan atau kesenjangan antara Kecamatan Bangkinang Kota sebagai Ibu Kota Kabupaten Kampar dengan kecamatan lainnya, maka dilakukan penyesuaian dengan kebijakan RTRW Kabupaten Kampar. Hirarki II sebagai sub pusat kecamatan tersebut memiliki posisi yang strategis. Kecamatan Tapung Hilir berada dekat dengan akses jalan nasional Pekanbaru-Dumai, Kecamatan Kampar Kiri Hilir dilintasi jalan kolektor primer yang menhubungkan Teluk Kuantan dengan Kota Pekanbaru, sedangkan Kecamatan XIII Koto Kampar merupakan gerbang masuk Provinsi Riau dari arah Sumatera Barat. Karena lokasi yang strategis maka berpeluang untuk mengambil peran sebagai satelit dari kawasan perkotaan serta mengambil peran dalam konstelasi yang lebih luas bersifat lintas wilayah. Pada hirarki IV terdiri dari 5 (lima) kecamatan, yaitu Kecamatan Bangkinang, Kecamatan Gunung Sahilan, Kecamatan Perhentian Raja, Kecamatan Salo, dan Kecamatan Kampar. Sedangkan pada hirarki V terdiri 8 (delapan) kecamatan, yaitu Kecamatan Kampar Kiri Tengah, Kecamatan Rumbio Jaya, Kecamatan Kuok, Kecamatan Kampar Timur, Kecamatan Koto Kampar Hulu, Kecamatan Tambang, Kecamatan Kampar Utara, dan Kecamatan Kampar Kiri Hulu.Kecamatan-kecamatan tersebut diarahkan dan dengan sendirinya menjadi pusat pelayanan lokal untuk melayani kecamatannya sendiri.

Dari hasilpenggabungan antara kebijakan RTRW dan hasil anlisis skalogram dan pelayanan di Kabupaten Kampar maka direkomendasikan Kecamatan Tapung, Kecamatan Kampar Kiri, Kecamatan Siak hulu, dan Kecamatan Tapung Hulu. Secara kebijakan dalam RTRW Kabupaten Kampar Kecamatan Tapung dan Kecamatan Kampar Kiri difungsikan untuk melayani beberapa kecamatan, sedangkan Kecamatan Siak Hulu dan Tapung Hulu dinilai layak berdasarkan analisis skalogram dengan memiliki jenis fungsi fasilitas 18 unit dari 19 unit fasilitas sosial ekonomi dan nilai sentralitas masing-masing sebesar 110 .

Hirarki III direkomendasikan Kecamatan Tapung Hilir, Kecamatan Kampar Kiri Hilir, dan Kecamatan XIII Koto Kampar dengan fungsi melayani kegiatan skala kecamatan atau desa,

indeks sentralitas maka dapat direkomendasikan pusat pelayanan di Kabupaten Kampar, untuk lebih jelas dapat dilihat pada Tabel 5 dan Gambar 1.

Tabel 5 Rekomendasi Struktur Pusat-Pusat Pelayanan di Kabupaten Kampar

\begin{tabular}{|c|l|c|}
\hline No & \multicolumn{1}{|c|}{ Kecamatan } & Hirarki \\
\hline 1 & $\begin{array}{l}\text { Kec. Bangkinang } \\
\text { Kota }\end{array}$ & I \\
\hline 2 & Kec. Tapung & II \\
\hline 3 & Kec. Kampar Kiri & II \\
\hline 4 & Kec. Siak Hulu & II \\
\hline 5 & Kec. Tapung Hulu & II \\
\hline 6 & Kec. Tapung Hilir & III \\
\hline 7 & $\begin{array}{l}\text { Kec. Kampar Kiri } \\
\text { Hilir }\end{array}$ & III \\
\hline 8 & $\begin{array}{l}\text { Kec. XIII Koto } \\
\text { Kampar }\end{array}$ & III \\
\hline 9 & Kec. Bangkinang & IV \\
\hline 10 & $\begin{array}{l}\text { Kec. Gunung } \\
\text { Sahilan }\end{array}$ & IV \\
\hline 11 & Kec. Perhentian Raja & IV \\
\hline 12 & Kec. Salo & IV \\
\hline 13 & Kec. Kampar & IV \\
\hline 14 & $\begin{array}{l}\text { Kec. Kampar Kiri } \\
\text { Tengah }\end{array}$ & V \\
\hline 15 & Kec. Rumbio Jaya & V \\
\hline 16 & Kec. Kuok & V \\
\hline 17 & Kec. Kampar Timur & V \\
\hline 18 & Kec. Koto Kampar & V \\
\hline
\end{tabular}




\begin{tabular}{|c|l|c|}
\hline & Hulu & \\
\hline 19 & Kec. Tambang & V \\
\hline 20 & Kec. Kampar Utara & V \\
\hline 21 & $\begin{array}{l}\text { Kec. Kampar Kiri } \\
\text { Hulu }\end{array}$ & V \\
\hline
\end{tabular}

Sumber : Hasil Analisis, 2017

\section{SIMPULAN DAN SARAN}

Dari draft RTRW Kabupaten Kampar dengan hasil analisis skalogram dan indeks sentralitas terdapat perbedaan struktur pusat-pusat pelayanan. Dari analisis skalogram dan indeks sentralitas tidak terdapat hirarki II dan hirarki III sehingga terjadi pemusatan fasilitas pada hirarki 1 yakni Kota Bangkinang sebagai ibukota Kabupaten.

Setelah dibandingkan struktur pusatpusat pelayanan di Kabupaten Kampar berdasarkan draft RTRW dengan analisis skalogram dan indeks sentralitas, maka direkomendasikan struktur pusat-pusat pelayanan di Kabupaten Kampar terdiri dari 5 hirarki yaitu hirarki I berada di Kecamatan Bangkinang Kota, hirarki II berada di Kecamatan Tapung, Kampar Kiri, Siak Hulu, dan Tapung Hulu, hirarki III berada di Kecamatan Tapung Hilir, Kampar Kiri Hilir, dan XIII Koto Kampar, hirarki IV berada di Kecamatan Bangkinang, Gunung Sahilan, Perhentian Raja, Salo, dan Kampar, hirarki V berada di Kecamatan Kampar Kiri Tengah, Rumbio Jaya, Kuok, Kampar Timur, Koto Kampar Hulu, Tambang, Kampar Utara, dan Kampar Kiri Hulu.

\section{DAFTAR PUSTAKA}

Ambardi, Urbanus M dan Socia Priwantoro. Pengembangan Wilayah dan Otonomi Daerah. BPPT press. Jakarta . 2002

Artiningsih, Sri Budi. 2006. Analisis Daya Tarik Dua Pusat Pelayanan Dalam Pengembangan Sistem Perkotaan Di Kabupaten Purworejo (Studi Kasus: Kota Kutoarjo Dan Kota Purworejo). Semarang : Universitas Diponegoro.
Badan Pusat Statistik.Kabupaten Kampar dalam Angka 2016. Kampar : BPS. Kecamatan Bangkinang dalam Angka 2016. Kampar : BPS. Kecamatan Bangkinang Kota dalam Angka 2016. Kampar : BPS. Kecamatan Gunung Sahilan dalam Angka 2016. Kampar : BPS.

Kecamatan Kampar dalam Angka 2016. Kampar: BPS.

Kecamatan Kampar Kiri dalam Angka 2016. Kampar : BPS.

Kecamatan Kampar Kiri Hilir dalam Angka 2016. Kampar : BPS.

Kecamatan Kampar KiriHulu dalam Angka 2016. Kampar: BPS.

Kecamatan Kampar Kiri Tengah dalam Angka 2016. Kampar: BPS.

Kecamatan Kampar Timur dalam Angka 2016. Kampar: BPS.

Kecamatan Kampar Utara dalam Angka 2016. Kampar : BPS.

Kecamatan Bangkinang dalam Angka 2016. Kampar: BPS.

Kecamatan Koto Kampar Hulu dalam Angka 2016. Kampar: BPS.

Kecamatan Kuok dalam Angka 2016. Kampar: BPS.

Kecamatan Perhentian Raja dalam Angka 2016. Kampar : BPS.

Kecamatan Rumbio Jaya dalam Angka 2016. Kampar: BPS.

Kecamatan Salo dalam Angka 2016. Kampar : BPS.

Kecamatan Siak Hulu dalam Angka 2016. Kampar: BPS.

Kecamatan Tapung dalam Angka 2016. Kampar : BPS.

Kecamatan Tapung Hilir dalam Angka 2016. Kampar: BPS.

Kecamatan Tapung Hulu dalam Angka 2016. Kampar : BPS.

Kecamatan XIII Koto Kampar dalam Angka 2016. Kampar : BPS.

Budiharsono, Sugeng. 2001. Teknik Analisis Pembangunan Wilayah Pesisir dan Lautan. Jakarta : PT. Pradnya Paramita.

Gaffara, Ghefra Rizkan, Ahmad Fathu dan Fatih. 2015. Kajian Skalogram Guttman Dan Indeks Sentralitas 
Marshall Untuk Penentuan PusatPusat Pelayanan Wilayah (Studi Kasus: Kabupaten Simalungun, Provinsi Sumatra Utara). Kampus Terpadu, Sleman.

Hariyanto, Asep. 2006. Percepatan Pengembangan Wilayah Melalui Strategi Implementasi Wilayah Pengembangan (WP) Dan Hirarki Kota-Kota (Studi Kasus : Kabupaten Subang). Jurnal PWK Unisba. Bandung.

Muta'ali, Lutfi. 2015. Teknik Analisis Regional untuk perencanaan wilayah, tata ruang dan lingkungan. Yogyakarta : Badan Penerbit Fakultas Geografi (BPFG).

Pane, Teguh Achmad. 2013. Kajian Pengembangan Pusat-Pusat Pelayanan di Wilayah Kabupaten Serdang Bedagai. Medan : Universitas Sumatera Utara.

Pramono, Riska Ayu. 2016. Analisis Faktor-Faktor yang Mempengaruhi Ketimpangan Wilayah di Provinsi Riau. Yogyakarta : Fakultas Ekonomika dan Bisnis Universitas Gajah Mada.

Setiawan, Didi, Zainuddin dan Ulfa Matoka. 2016. Analisis Fungsi Pelayanan Kecamatan-Kecamatan di Bagian Timur Kabupaten Konawe Selatan. Jurnal Ekonomi Vol. 1, April 2016 Page 44-55. Jurusan Ilmu Ekonomi, Universitas Halu Oleo.

Tarigan, Robinson. 2015. Perencanaan Pembangunan Wilayah, edisi revisi. Jakarta : Bumi Aksara.

Viduri, Vika, Badjuri dan Andjar Widjajanti. 2015. Analisis Pengembangan Wilayah Kecamatan sebagai Pusat Pertumbuhan dan Pusat Pelayanan di Kabupaten Banyuwangi dalam Artikel Ilmiah Mahasiswa 2015. Jurusan Ilmu Ekonomi dan Studi Pembangunan Fakultas Ekonomi Universitas Jember (UNEJ).

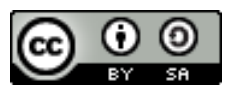

This is an open access article which means that all content is freely available without charge to the user or his/her institution. Jurnal Saintis allows the author(s) to hold the copyright without restriction. The copyright in the text of individual articles (including research articles, opinion articles, and abstracts) is the property of their respective authors distributed under the terms of the Creative Commons Attribution-ShareAlike 4.0 International License(https://creativecommons.org/licenses/by-sa/4.0/) which permits unrestricted use, distribution, and reproduction in any medium. Users are allowed to read, download, copy, distribute, search, or link to full-text articles in this journal without asking by giving appropriate credit, provide a link to the license, and indicate if changes were made. 
Tabel 4 Perbandingan Hirarki Struktur Ruang RTRW dan Hasil Analisis Hirarki Pusat Pelayanan Peneliti

\begin{tabular}{|c|c|c|c|c|c|c|}
\hline \multirow{2}{*}{ No } & \multicolumn{2}{|c|}{ RTRW Kabupaten Kampar Tahun 2010-2030 } & \multirow{2}{*}{ No } & \multicolumn{2}{|c|}{ Hasil Analisis } & \multirow{2}{*}{ Hirarki } \\
\hline & Hirarki Fungsi & Kecamatan & & Nilai Indeks Sentralitas & Kecamatan & \\
\hline 1 & $\begin{array}{l}\text { PKW (Pusat Kegiatan } \\
\text { Wilayah) }\end{array}$ & - Kec. Bangkinang Kota & 1 & $\begin{array}{l}\text { Nilai Indeks Sentralitas } \\
\text { Sangat Tinggi }\end{array}$ & - Kec. Bangkinang Kota & I \\
\hline 2 & $\begin{array}{l}\text { PKLp (Pusat Kegiatan } \\
\text { Lokal Promosi) }\end{array}$ & $\begin{array}{l}\text { - Kec. Tapung } \\
\text { - Kec. Kampar Kiri }\end{array}$ & 2 & $\begin{array}{l}\text { Nilai Indeks Sentralitas } \\
\text { Tinggi }\end{array}$ & - & II \\
\hline 3 & $\begin{array}{l}\text { PPK (Pusat Kegiatan } \\
\text { Kawasan) }\end{array}$ & $\begin{array}{l}\text { - Kec. Tapung Hilir } \\
\text { - Kec. Kampar Kiri Hilir } \\
\text { - Kec. XIII Koto Kampar }\end{array}$ & 3 & $\begin{array}{l}\text { Nilai Indeks Sentralitas } \\
\text { Sedang }\end{array}$ & - & III \\
\hline 4 & $\begin{array}{l}\text { PPL (Pusat Pelayanan } \\
\text { Lingkungan) }\end{array}$ & $\begin{array}{l}\text { - Kec. Kampar Kiri Hulu } \\
\text { - Kec. Gunung Sahilah } \\
\text { - Kec. Perhentian Raja } \\
\text { - Kec. Kampar Kiri Tengah } \\
\text { - Kec. Tambang } \\
\text { - Kec. Kuok } \\
\text { - Kec. Salo } \\
\text { - Kec. Tapung Hulu } \\
\text { - Kec. Bangkinang } \\
\text { - Kec. Kampar } \\
\text { - Kec. Kampar Timur } \\
\text { - Kec. Rumbio Jaya } \\
\text { - Kec. Kampar Utara }\end{array}$ & 4 & $\begin{array}{l}\text { Nilai Indeks Sentralitas } \\
\text { Rendah }\end{array}$ & $\begin{array}{l}\text { - Kec. Siak Hulu } \\
\text { - Kec. Tapung Hulu } \\
\text { - Kec. Tapung } \\
\text { - Kec. Tapung Hilir } \\
\text { - Kec. Bangkinang } \\
\text { - Kec. Gunung Sahilan } \\
\text { - Kec. Perhentian Raja } \\
\text { - Kec. Salo } \\
\text { - Kec. Kampar }\end{array}$ & IV \\
\hline & & & 5 & $\begin{array}{l}\text { Nilai Indeks Sentralitas } \\
\text { Sangat Rendah }\end{array}$ & $\begin{array}{l}\text { - Kec. Kampar Kiri Tengah } \\
\text { - Kec. Rumbio Jaya } \\
\text { - Kec. Kuok } \\
\text { - Kec. XIII Koto Kampar } \\
\text { - Kec. Kampar Timur } \\
\text { - Kec. Kampar Kiri } \\
\text { - Kec. Koto Kampar Hulu } \\
\text { - Kec. Kampar Kiri Hilir } \\
\text { - Kec. Tambang } \\
\text { - Kec. Kampar Utara } \\
\text { - Kec. Kampar Kiri Hulu }\end{array}$ & V \\
\hline
\end{tabular}


Kajian Pusat-Pusat Pelayanan Di Kabupaten Kampar (Rona Muliana,dkk)

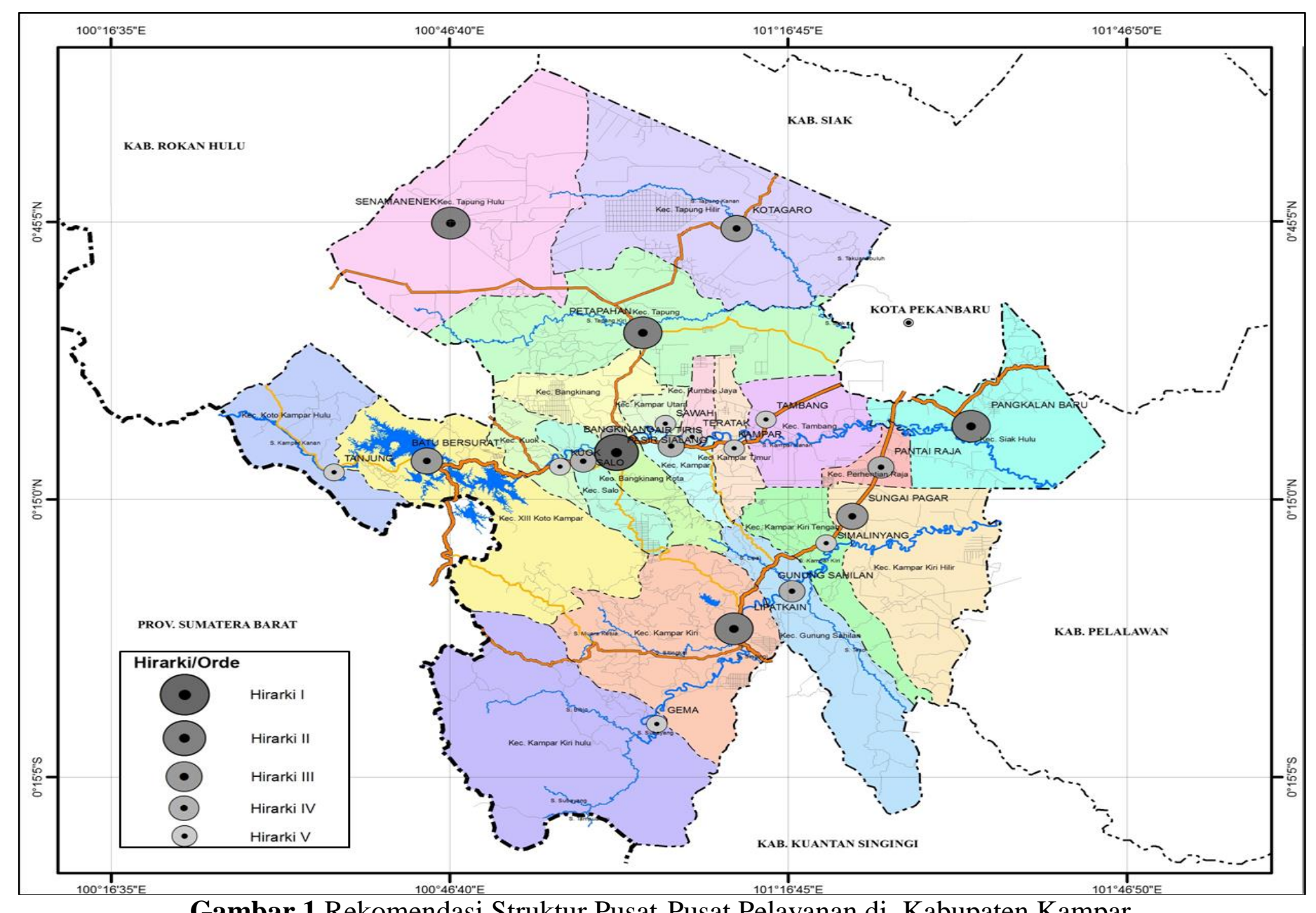

Gambar 1 Rekomendasi Struktur Pusat-Pusat Pelayanan di Kabupaten Kampar 
J. Saintis Volume 18 Nomor 1, 2018

Halaman ini sengaja dikosongkan 